\title{
Single-Gene Determinants of Epilepsy Comorbidity
}

\author{
Jeffrey L. Noebels \\ Developmental Neurogenetics Laboratory, Departments of Neurology, Neuroscience, and Molecular \\ and Human Genetics, Baylor College of Medicine, Houston, Texas 77030 \\ Correspondence: jnoebels@bcm.edu
}

Common somatic conditions are bound to occur by chance in individuals with neurological disorders as prevalent as epilepsy, but when biological links underlying the comorbidity can be uncovered, the relationship may provide clues into the origin and mechanisms of both. The expanding list of monogenic epilepsies and their associated clinical features offer a remarkable opportunity to mine the epilepsy genome for coordinate neurodevelopmental phenotypes and examine their pathogenic mechanisms. Defined single-gene-linked epilepsy syndromes identified to date include all of the most frequently cited comorbidities, such as cognitive disorders, autism, migraine, mood disorders, late-onset dementia, and even premature lethality. Gene-linked comorbidities may be aggravated by, or independent of, seizure history. Mutations in these genes establish clear biological links between abnormal neuronal synchronization and a variety of neurobehavioral disorders, and critically substantiate the definition of epilepsy as a complex spectrum disorder. Mapping the neural circuitry of epilepsy comorbidities and understanding their single-gene risk should substantially clarify this challenging aspect of clinical epilepsy management.

$\mathrm{C}$ omorbid conditions are prevalent in epilepsy and actually exceed the disability caused by seizures themselves (Lin et al. 2012); over a lifetime, their diagnosis and treatment more than doubles the overall economic burden of the disorder (Cramer et al. 2014). Classically, the term "comorbidity" was introduced by Feinstein to denote cases in which "a distinct additional clinical entity" occurred during the clinical course of a patient presenting with an index disease. A search for the cause of a contemporaneous problem and whether it is connected to a common pathogenic mechanism is a routine task in neurological diagnosis, and has a significant impact on health care. Yet in the epilepsy clinic, the biological underpinnings of comorbidity are often poorly understood, and by virtue of the early and profound impact seizures may exert on normal brain development, often believed to arise as a result of the seizures themselves. This need not be so. Although the clinical history in epilepsy typically defines the initial symptom as primary, comorbidities can arise before, during, or after onset of the first seizure, and their temporal appearance may have little bearing on whether the two are connected by a common biological mechanism. An essential task for the clinician, therefore, is to develop a working hypothesis that relegates the conjugal relationship to one of three etio-

Editors: Gregory L. Holmes and Jeffrey L. Noebels

Additional Perspectives on Epilepsy: The Biology of a Spectrum Disorder available at www.perspectivesinmedicine.org

Copyright (C) 2015 Cold Spring Harbor Laboratory Press; all rights reserved; doi: 10.1101/cshperspect.a022756

Cite this article as Cold Spring Harb Perspect Med 2015;5:a022756 
J.L. Noebels

logical categories: (1) an independent comorbidity (shared but unrelated concurrent dysfunction in different brain pathways), (2) a consequent comorbidity (direct result of the primary disease), or (3) an iatrogenic comorbidity (treatment-related). Uncertainty among these alternatives is a major determinant of unfavorable medical outcomes, and may lead to an incorrect diagnosis, polypharmacy and its complications, or an erroneous prognosis.

\section{ACQUIRED VERSUS INBORN: ISOLATING THE ROOTS OF SEIZURE COMORBIDITY}

Seizure disorders, in all of their protean manifestations, are common throughout the life span and arise from both acquired and genetic lesions. The same is true of a number of neurodevelopmental and adult-onset cognitive, psychiatric, and neurological syndromes, which, even when coexpressed in the context of epilepsy, are considered disorders in their own right. This means that multiple independent etiologies of the syndromic elements are always a leading possibility. Alternatively, they may be a shared downstream sequelae of a single common etiology; for example, acquired brain injuries account for up to one-third of individuals with epilepsy, yet can lead to cognitive and psychiatric syndromes throughout the life span whether seizures are present or not.

Acquired seizure disorders arise from neural injuries that are highly variable in pathobiology, timing, and severity. These range from neonatal hypoxia characterized by diffuse pancellular patterns of cell death and inflammation, along with encephalitides, hemorrhagic stroke, and penetrating brain trauma, to the opposite extreme, such as adult-onset autoimmune disorders with precisely defined, antigen-specific molecular lesions of membrane channels and glutamatergic and GABAergic synaptic neurotransmission (Lancaster and Dalmau 2012). Each of these extrinsic insults may occur at almost any stage of brain development, disrupt entirely different patterns of brain function, and with the distinct exception of autoimmune processes, are of little value in localizing the circuitry of the functional defect, particularly when they are not exactly correlated with the actively discharging epileptic networks. Dissecting causal mechanisms underlying acquired seizure comorbidities is a challenge because it can rarely be determined with confidence that the comorbid disturbance might not have emerged regardless of the seizures and subsequent medication. Short of a complete resolution once the seizures are controlled, the codependent relationship is uncertain, and, in the case of migraine (Hoffmann et al. 2014) and some mood disturbances (Oncu et al. 2014; Selle et al. 2014), remains unproven, because the two disorders are often treatable by the same antiepileptic drug (AED) even in the absence of the other.

In contrast, inherited epilepsies offer a far more tractable framework to analyze comorbidity, namely, whether mutation of a single gene can produce seizures along with a coordinate, nonepileptic phenotype. The discovery of mutations in single genes that give rise to both seizures and comorbid conditions provides compelling evidence for genetically interdependent mechanisms, and a clear path to dissect the underlying biology, because they should each display relatively stereotyped natural histories. Genes linked to epilepsy and coordinate phenotypes indicate that a single molecular lesion can alter immature neuronal circuits at multiple stages, with a profound pleiotrophic impact on early brain development (Fig. 1).

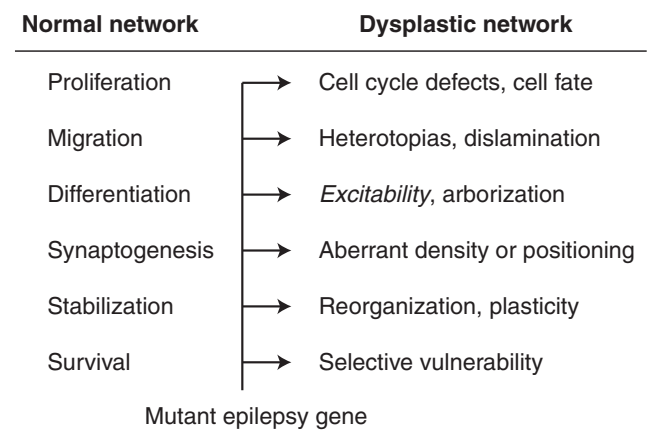

Figure 1. A monogenic basis for epilepsy comorbidity. Single genes contribute to distinct biology at multiple levels of brain development. Mutations, even within the same gene, can lead to highly selective patterns of pathophysiology. 
In epilepsy patients, the functional effect of these gene mutations can alter both the dynamic and the static behavior of neural circuits, and the distinction has profound clinical significance. When epileptiform activity disrupts neural network signaling and produces a comorbid deficit that is promptly regained once seizures are eliminated, the encephalopathic deficit is considered "epileptic" in origin. Epileptic pseudodementia (Tatum et al. 1998), migraine (Rogawski 2012), and depression (Kanner 2011) are important examples. The active contribution of interictal electroencephalogram (EEG) discharges to persistent cognitive decrements in the absence of seizures is an interesting but still unresolved issue (Holmes 2014). However, when either the mutated gene itself or the damage that seizures produce result in prolonged interictal disruption of cortical function, and the comorbid symptoms persist despite effective seizure control, a more complex and potentially instructive relationship is present.

In this group, the biological nature of the gene defect in neural circuitry largely determines the spectrum of the comorbid phenotypes. This enables a series of questions for subsequent investigation. Does the causative gene for epilepsy lead directly to the pleiotrophic appearance of a second disorder as a result of the early onset or severity of the seizures themselves, or are they each the product of seizure-independent downstream mechanisms? Does the molecular lesion affect overlapping cell types across widespread brain regions, or distinct cellular compartments in specific cortical networks? Are the seizures sufficiently severe to trigger cell death, or is there a window of opportunity where early recognition and therapeutic cellular and molecular remodeling could reshape the outcome? These issues are of extraordinary significance for therapeutic targeting, because they determine whether stopping or preventing the seizures could ameliorate the entire syndrome, which otherwise will continue whether seizures are controlled or not. Because the answers may differ for each epilepsy gene, the value of individual clinical gene profiles will increase as each becomes better understood.
This article provides illustrative examples of gene-linked comorbidities in epilepsy, including cognitive disorders of early and later life, autism, mood (mania, depression, bipolar, ADDH, schizophrenia), migraine, and premature death genes. These genes clearly strike more than one brain network, resulting in a complex clinical phenotype. A focus on these mechanistic pathways, as studied in mouse models and in humans, will hopefully lead to novel therapies and personalized management of persons with complex epilepsy comorbidities.

\section{COORDINATE PHENOTYPES OF SINGLE EPILEPSY GENES}

The study of monogenic epilepsies has highlighted several broad issues. First, virtually every known inherited epilepsy syndrome can be caused by more than one gene, and, second, each gene typically causes more than one syndrome. This means that for any broadly defined clinically epilepsy syndrome, for example, epileptic encephalopathy, we expect an innate spectrum of distinct comorbidities depending on the gene in question. An interesting example is presented by two genes for the childhood syndrome of autosomal dominant frontal lobe epilepsy (ADNFLE), the nicotinic cholinergic receptor nAchR4 (Steinlein et al. 1995), and the sodium-sensitive potassium channel KCNT1, where human mutations are associated with epilepsy and severe intellectual disability and developmental delay (Heron et al. 2012b; Kim and Kaczmarek 2014). Despite a similar seizure phenotype, intellectual disability only occurs in the Slack channel mutations (Steinlein 2014).

Third, the phenotypic seizure spectrum of any single gene for epilepsy is itself typically broad, leading to mild and severe seizure phenotypes, with either early or late onset. The heterogeneity of seizure severity and age of onset are well-known features of mutations in voltagegated ion channels, the largest and best-studied category of inherited epilepsy to date, and depend on properties of the specific mutation within the gene (Zuberi et al. 2011), the epistatic genetic complexity of each individual (Klassen et al. 2011), or both. The sheer number of 
J.L. Noebels

specific genes with multifunctional intragenic domains, and the array of mutations (gain or loss of function) found within each of them represent a major challenge to prognosis, and much research remains to decipher the clinical utility of individual gene profiles.

Nevertheless, a prominent group of genes have been discovered in epilepsy syndromes that are solid biomarkers of other neurodevelopmental and psychiatric conditions, such as cognitive disorders, autism, attention-deficit hyperactivity disorder (ADHD)/mood disturbances, and migraine. The genetic overlap with early-onset cognitive disorders and autism is particularly notable (Betancur 2011). Other genes reveal phenotypic overlap with movement disorders (dyskinesias) (Heron et al. 2012a), ataxias (Matsuura et al. 2000; Ortolano et al. 2014), and late-onset dementias (Lopera et al. 1997). The latter illustrate how a seizure disorder can appear alongside or in the wake of another neurological deficit during its neurodegenerative trajectory. In general, as circuits fail within the brain, they may progress through a stage where an inhibitory imbalance predominates, leading to network dysrhythmia and seizures. These genes bridge the traditionally narrow perspective of epilepsy as a static monomorphic hyperexcitability disorder with the broader view of a collection of more dynamic synchronization disorders that mark different stages of brain disease arising from errors of cell proliferation, cell migration, and synaptogenesis on the one hand, and inflammation, cell death, and homeostatic repair on the other.

\section{SINGLE-GENE COMORBIDITIES}

\section{Mixed Seizure Types}

From a strictly mechanistic standpoint, one category of epilepsy comorbidity is underappreciated but actually very common, namely, the coexistence of multiple seizure types that clearly involve distinct cellular networks in the brain. Examples include individuals with multiple seizure types, such as infantile spasms followed by convulsive epilepsy in $A R X$ mutations or staring spells followed by the onset of convulsive seizures, a common occurrence in childhood absence epilepsy. Experimentally, these have been reproduced in monogenic-engineered single-gene mouse models (Price et al. 2009), or by combining two different genes (Serikawa and Yamada 1986). The glucose transporter gene GLUT1 is another leading example of a monogenic complex seizure phenotype. This membrane transporter mediates glucose uptake across the blood-brain barrier, is present throughout the brain, and loss-of-function mutations give rise to diverse neurological syndromes with multiple seizure types in children (Pearson et al. 2013). Various GLUT1 mutations are found in individuals with childhood absence epilepsy, generalized seizures, and movement disorders, sometimes even without accompanying seizures. Paroxysmal dyskinesia occurs in some individuals along with a range in severity of intellectual impairment. Several seizure types have been documented in mice homozygous for Glut1 deletion (Wang et al. 2006), validating the complex seizure phenotype of this gene. Lennox-Gastaut syndrome is another epileptic encephalopathy with multiple seizure types (Camfield 2011) and emerging gene candidates (Lund et al. 2014; Terrone et al. 2014).

\section{Developmental Epileptic Encephalopathies}

Gene discovery in this complex neurodevelopmental phenotype has accelerated to a once unimaginable pace with the advent of clinical exome analysis for de novo mutations in infantile and childhood epilepsy accompanied by cognitive delay. Beginning with $A R X$ (Stromme et al. 2002), over 100 genes for early-onset seizures with intellectual disability are listed in the Online Mendelian Inheritance in Man (OMIM) database. The extent and heterogeneity of this major comorbid genetic overlap is of scant surprise, because microcircuits in the hippocampus and entorhinal cortex, essential for proper memory storage and retrieval, are also extremely low-threshold initiation sites for seizures when lesions are placed experimentally in limbic circuitry (Kleen et al. 2012). The diverse molecular contribution to neuronal synchrony in these circuits means that not each gene model 
will necessarily perturb seizure threshold and cognitive performance to a similar extent. Early gene lesions in immature brain may be either less injurious and more easily reversed or severe, depending on the mutant allele. Benign neonatal familial seizures as a result of missense mutations in the KCNQ2 potassium channel gene (Singh et al. 1998) were modeled in mice and found to leave little trace of hippocampal reorganization (Singh et al. 2008). Subsequently, it was recognized that dominant negative mutations in the same gene gave rise to the far more severe cognitive deficits of Ohtahara syndrome (Saitsu et al. 2012). A similar monogenic phenotypic spectrum is well known for mutations within the sodium channel gene SCN1A underlying uncomplicated generalized febrile seizures and the encephalopathy of Dravet syndrome. Other genes may even show a positive dissociation between epilepsy and cognitive impairment. A striking example of the latter is provided by the $P K R$ gene encoding a double-stranded RNA-activated protein kinase whose deletion enhances the late phase of hippocampal long-term potentiation (LTP), increases network excitability, and elevates cognitive performance in behavioral tasks while reducing GABAergic inhibition and the threshold for spontaneous seizures (Zhu et al. 2011).

\section{Deconstructing the Circuitry of Comorbid Cognitive Deficits}

Further evidence for the impact of epilepsy within learning and memory circuits can be gained by analyzing conditional rather than genomic gene expression in mouse models. The ability to focally express pathogenic mutations within specific brain networks facilitates the isolation of necessary and sufficient pathways underlying the comorbidity phenotype. For example, Bender et al. (2012) showed that selective reduction of Scnla in subcortical circuits produced cognitive dysfunction in the absence of the epilepsy seen in the genomic deletion model. This powerful strategy to isolate anatomical substrates of normal cognitive function can be extended to explore the role of specific cell types and developmental critical periods using condi- tional drivers of gene expression, and promises to pinpoint future molecular targets and critical opportunities for therapeutic intervention. It is worth noting, however, that these methods fall short of defining the full extent of participating brain networks in developing brain. Although transgenic expression can be precisely controlled within the confines of specific cell types, the developmental influence of mutant cells on synaptically linked nonmutant networks extends the functional pathophysiology. For example, primary impairment of interneurons is tightly coupled to use-dependent changes in excitatory cells, leaving the contributions of each to the overall phenotype less distinct. In Rett syndrome models, selective deletion of $M E C P 2$ in interneurons produces a disease phenotype, but so does deletion in excitatory neurons (Chao et al. 2010; Zhang et al. 2014). Analysis of the epileptic encephalopathy gene KCNT1, a sodium-activated potassium channel (Slack) (Heron et al. 2012), reveals that mutations disrupting the carboxy-terminal proteinprotein interactions of Slack with cytoplasmic signaling molecules contribute to intellectual disability, and show molecular interactions with other cognitive genes, such as FMRP.

\section{Autism}

Depending on the cohort examined, the clinical epidemiology of autism spectrum disorder (ASD) includes epilepsy as a feature in up to one-third of individuals (Matsuo et al. 2010). Of the genes associated so far with autism behavioral features, a growing fraction display epileptic phenotypes in both human and mouse models (Fig. 2). Although the neural circuitry of autism is poorly defined and extends beyond regions traditionally critical for epilepsy, such as the cerebellum, genetic evidence for overlapping biology in the synaptic compartment of forebrain networks is sufficiently compelling to assume that these comorbidities can be functionally linked. The principle mechanisms affected are neurotransmission and DNA methylation/chromatin remodeling. Recent exome sequencing in a large autism cohort revealed 27 gene candidates with de novo loss-of-function mutations and 
J.L. Noebels
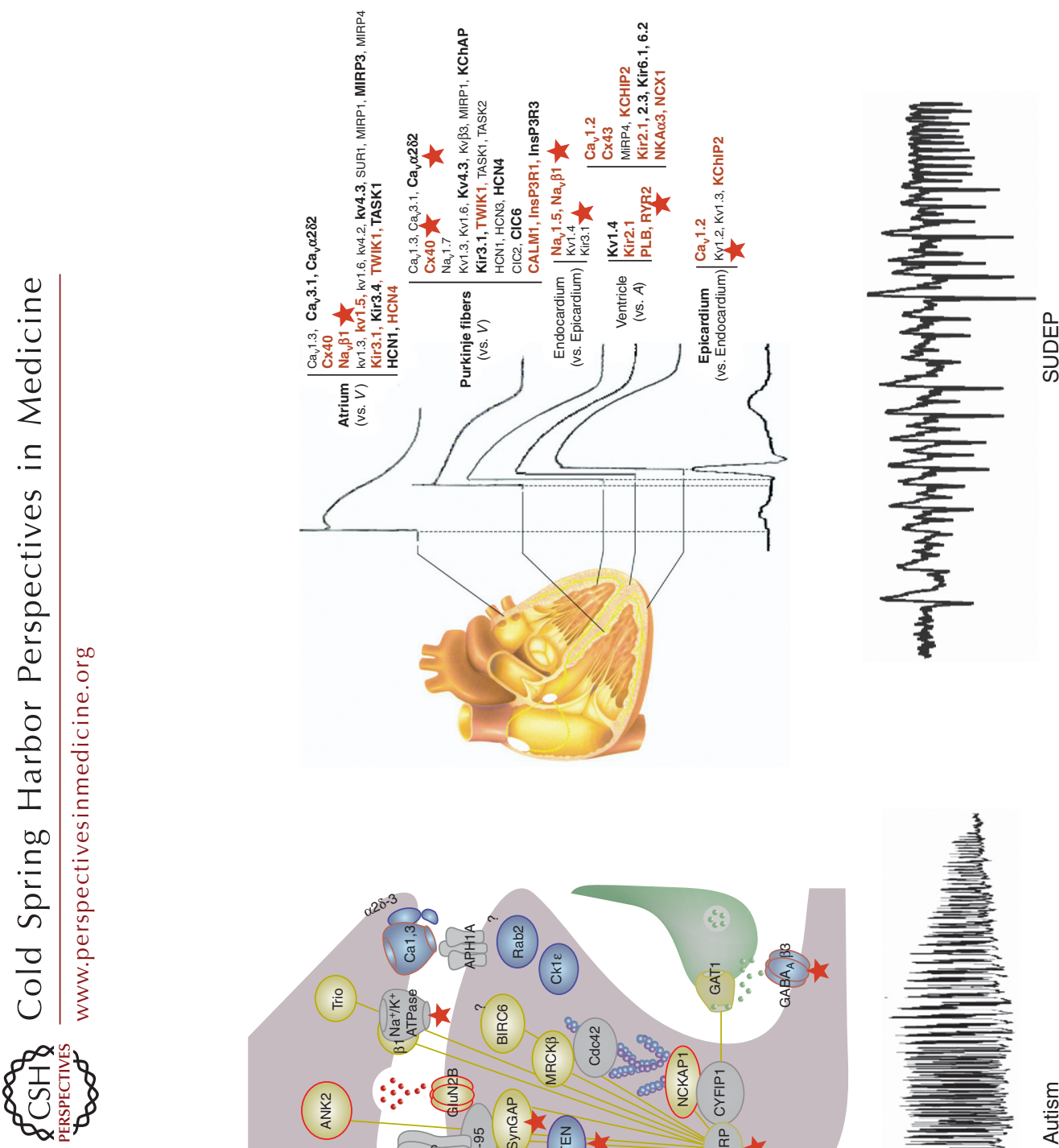

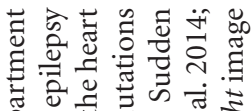

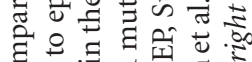

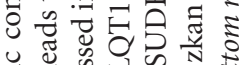

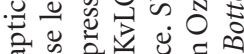

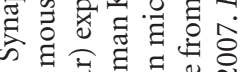

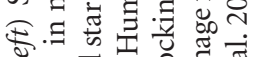

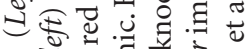
$\dot{0}=\hat{0}=0$

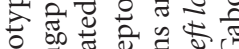

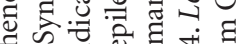

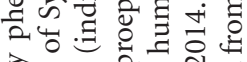

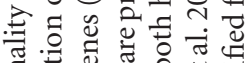

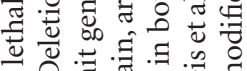

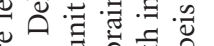

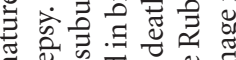
घี के चू పे चै

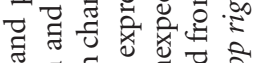
घี ฮี Ð

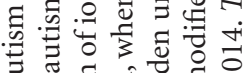
ప

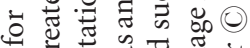
তั 은

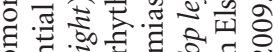

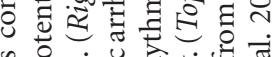
\& …

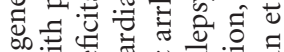

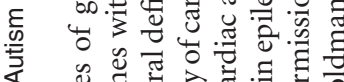
\& घี

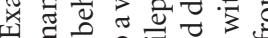

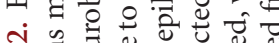
ช.

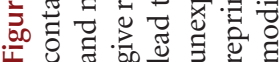

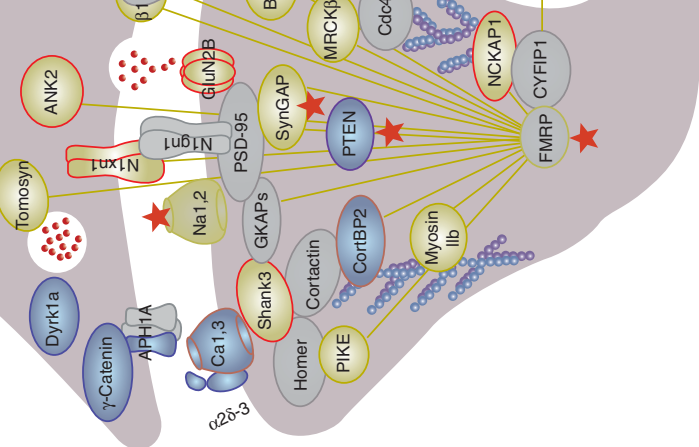


$>1500$ with de novo missense variants (Iossifov et al. 2014). Of these six, CHD8, DYRK1A, ANK2, GRIN2B, DSCAM, and CHD2 were identified in three or more people with autism. A second study (De Rubeis et al. 2014) added ADNP, SCN2A, SYNGAP1, and TBR1. Still other candidates include NRX1, CNTN4, DCLK2, CNTNAP2, CATNAP4, TRIM32, MBD5, ASTN2, CNTN5, GABRG1, SYN1, and CHRNA7.

More than a few of these genes produce robust epilepsy and social interaction deficits when deleted in mouse models. SYNGAP1, a synaptic Ras GTPase-activating protein, is interesting because the primary functional defect in Syngap1deficient epileptic mice appears to reside in excitatory neurons (Ozkan et al. 2014). CNTNAP2 and family members are membrane proteins involved in ion channel localization that lead to autism and epilepsy (Penagarikano et al. 2011). Initially believed to reside primarily in excitatory cells, CNTNAP4 has recently been found to be enriched in interneurons (Karayannis et al. 2014). Recent work with the gene PRICKLE1, which contributes to both autism and epilepsy phenotypes, reveals an interaction of Prickle protein with synapsin 1, a second exocytosis-related protein linked to epilepsy (Paemka et al. 2013). The evaluation of variants within the presynaptic protein interactome provide an opportunity to functionally integrate variants contributing to risk, as well as a model for further phenotypic diversity based on finely sculpted perturbations of neurotransmitter release.

Fragile X syndrome (FXS), because of a silencing of the gene and loss of FMR protein, is among the most common monogenic cause of autism, responsible for $2 \%-6 \%$ of all ASD cases, and includes cognitive impairment, seizures, hyperactivity, attention deficit, and impulsivity as leading features of the syndrome (Kidd et al. 2014). Epilepsy prevalence is elevated in cases with FMR1 mutations, with a range of $14 \%-$ $44 \%$. Seizures are typically both generalized and partial, a majority resolve during childhood, and many FXS children without overt seizures show abnormal EEG centrotemporal spikes resembling benign focal epilepsy of childhood. Several candidate mechanisms triggered by the loss of fragile $\mathrm{X}$ mental retardation protein
(FMRP) have been proposed to cause the epilepsy of FXS, centering on dysregulation of excitatory mGluR and inhibitory GABA receptor pathways. Although spontaneous seizures (epilepsy) have not been reported in the Fmr1-deletion mouse model of FXS, these mice display dendritic pathology, defective synaptic plasticity, and a lowered threshold for evoked audiogenic seizures, and have proven useful in attempts to rescue hyperexcitability in this disorder (Bianchi et al. 2012; Dolan et al. 2013).

Other genetic syndromes display autism/ epilepsy comorbidity. Angelman syndrome includes autism, hyperactivity, and epilepsy, and is typically caused by silencing of a region of imprinted genes on chromosome 15 that includes UBE3a and $\mathrm{GABA}_{\mathrm{B}} 3$, both of which lead to epilepsy and behavioral deficits when deleted in mouse single-gene models (DeLorey et al. 1998; Jiang et al. 1998). Tuberous sclerosis is one of the largest identifiable causes of epilepsy and autism and is frequently associated with ADHDlike symptoms, which affect $30 \%-60 \%$ of children with Tourette syndrome (TS) (Curatolo et al. 2008; D’Agati et al. 2009) children. Mammalian target of rapamycin (mTOR) signaling is directly involved in TS cellular pathology, autism, and epilepsy, and represents a potential key molecular pathway joining these phenotypes (Lipton and Sahin 2014). Despite their strong clinical coincidence, nearly $70 \%$ of autism syndromes and early-onset epilepsy share a strong comorbidity with ADHD (Lo-Castro and Curatolo 2014); ADHD genes, with the exception of CHRNA7, GRIN2A, and SNAP25 show little overlap with known epilepsy loci (Li et al. 2014).

In a study of patients with childhood-onset epilepsy (Matsuo et al. 2010), nearly half (46\%) of clinical autism features arose after the onset of seizures. The finding that some of these features can be partially reversible by antiepileptic therapy requires significant further clinical research (Camacho et al. 2012).

\section{Depression}

With a lifetime prevalence of nearly 35\%, the clinically heterogeneous disorder of depression is the leading, most common psychiatric com- 
plication of epilepsy (Tellez-Zenteno et al. 2007), yet there is little firm evidence for comorbidity caused by the mutation of any single gene. Substantial human and animal investigation has focused on the limbic system as a shared anatomical substrate for epilepsy and depression, but the models are primarily based on chemical interventions and suffer from the difficulty in equating motor behavior profiles with depression-like human symptomatology (Nestler and Hyman 2010; Epps and Weinshenker 2013). Imaging studies reveal an overlap in structural, hypometabolic, and serotonergic receptorbinding changes in limbic brain regions where chronic epilepsy patients show abnormalities, in particular, the left orbitofrontal and anterior cingulate cortex (Kanner et al. 2012).

Although epidemiologic evidence suggests that up to $50 \%$ of the risk for depression is genetic (Nestler et al. 2002), few genes are established for major depressive disorder (MDD) (Gatt et al. 2015). The leading pathogenic models center on monoaminergic, glutamatergic, and GABAergic neurotransmission, and molecules involved in their release and reuptake at synapses, and some genes in these pathways include epilepsy phenotypes. For example, deletion of the glial glutamate uptake transporter GLT1 (Rothstein et al. 1996; Tanaka et al. 1997), a candidate gene for depression, produces epilepsy in mice with a very specific pattern of excitotoxic hippocampal pyramidal cell death. This extensive neurotransmitter overlap may explain what has been considered to be the "bidirectional" risk of depression and epilepsy (Kanner 2011), and likely contributes to the therapeutic overlap of antiepileptic pharmacology (Vasudev et al. 2012; Cipriani et al. 2013; Hernan et al. 2014; Dutta et al. 2015). Genetic associations of human epilepsy with the serotonin pathway remain inconclusive; however, available data from animal experiments suggest that genes in these pathways remain strong candidates for seizure comorbidity (Bragatti et al. 2014; Lacey et al. 2014). In mouse models, epilepsy resistance has been attributed to serotonergic hyperinnervation (Tripathi et al. 2008); seizures downregulate 5HTB receptors (Koh et al. 2007), and deletion of the 5HTC2 receptor subunit lowers the threshold for audiogenic seizures (Brennan et al. 1997).

\section{Alzheimer's Dementia}

It is of historical interest that the first descriptions of senile plaques were actually made in epilepsy patients (Catala and Poirier 2012), and Alzheimer's first report referred to these cases. Although long considered a rare and incidental comorbidity, the risk of epilepsy is now known to rise significantly above age-matched controls without dementia, and is extremely elevated in early-onset familial Alzheimer's Disease (AD) (Amatniek et al. 2006). Individuals with mutations in three known genes for Alzheimer's disease (AD) (PSEN1, PSEN2, and APP) show a dramatic elevation of epilepsy risk (Noebels 2011). Moreover, beginning with the first transgenic mouse model of AD (LaFerla et al. 1995), almost every mouse model of AD displays either convulsive or nonconvulsive seizures.

The evidence that pathological $A \beta$ accumulation is linked to neural network hyperexcitability and is proepileptogenic continues to accrue. This unexpected finding is one of the more fascinating to emerge recently in the neurobiology of disease. Although there is no data that seizures can initiate the signature cellular plaque and tangle neuropathology of $\mathrm{AD}$, several lines of evidence suggest they accelerate $A \beta$ accumulation (Cirrito et al. 2005), excitotoxic synaptic dysplasia (Velez-Pardo et al. 2004), and neuronal cell death in overlapping circuits leading to accelerated cognitive decline (Palop et al. 2007; Vossel et al. 2013). Early evidence has emerged that antiepileptic treatment in AD may slow the progression of the disorder (Sanchez et al. 2012). Interestingly, genes that suppress the pathophysiology of $A \beta$ overexpression and protect against cognitive decline, such as MAPT1 (tau) (Roberson et al. 2011), also prevent epilepsy in ion channel mutant models of epilepsy (Holth et al. 2013; Gheyara et al. 2014).

\section{Deficits of Higher Cortical Function}

Genes regulating the physiology of cortical association areas can cause epilepsy in association 
with other deficits of higher cortical function including aphasias. SRPX2, a human language and epilepsy-associated gene promoting synaptogenesis in language regions of the cerebral cortex is the target of the transcription factor FOXP2 (Sia et al. 2013). SRPX2 reduction impairs development of ultrasonic vocalization in mice. Interactors with SRXP2 have been identified by yeast 2-hybrid analysis of a human brain cDNA library (Royer-Zemmour et al. 2008), including two other known epilepsy genes, urokinase-type plasminogen activator receptor (UPAR or PLAUR) (Powell et al. 2003) and cathepsin B (CTSB) (Pennacchio et al. 1998), involved in extracellular proteolysis in human and rat brain. GRIN2A has also been linked to epilepsy in the rolandic region and aphasia (Reutlinger et al. 2010).

\section{Migraine}

A clinical relationship between migraine and epilepsy is well established (Rogawski 2012). Genes for a subtype of complicated migraine, familial hemiplegic migraine, have been identified and mutations linked to epileptic phenotypes (Pietrobon and Moskowitz 2013). The P/Q type, high-threshold voltage-gated calcium channel that regulates presynaptic neurotransmitter release was the initial genetic link discovered in human patients (Ophoff et al. 1996). Mouse models of this mutation (Tottene et al. 2009), but not a loss-of-function mutation (Ayata et al. 2000), shows seizures and a striking decreased threshold for the phenomenon of spreading depolarization within cortical pathways, believed to be the substrate of the hemiplegic migrainous deficit. Subsequently, two other genes encoding the $\mathrm{Na}^{+} \mathrm{K}^{+}$ATPase $\alpha 2$ subunit and $\mathrm{Na}_{\mathrm{v}} 1.1$ sodium channel have been similarly linked, and mutations in all three of these genes also lead to epileptic phenotypes in human and mouse models (Russell and Ducros 2011). The clinical utility of AEDs in migraine prophylaxis is well known (Hoffmann et al. 2014).

\section{Premature Death}

Genes linking seizures, central autonomic disorders, and premature mortality underlying sudden unexpected death in epilepsy (SUDEP) are vivid examples of inherited comorbidity in epilepsy. Beginning with the finding that SCN5A, a cardiac long QT interval syndrome (LQTS) sodium channel gene linked to sudden death is expressed in the amygdala (Hartmann et al. 1999), the limbic nucleus regulating cardiac representation in the forebrain, human mutations in the KCNQ1 potassium channel (the most common cause of human LQTS and sudden death) were evaluated in mouse models and shown to replicate the SUDEP phenotype (Goldman et al. 2009), pointing to other LQT genes as candidates for shared epilepsy-cardiac arrhythmia phenotypes (Fig. 2). KCNA1 is a second, non-LQTS potassium channel linked to brainstem and vagal nerve-driven cardiac arrhythmias, severe seizures, and early mortality (Glasscock et al.2010). Sentrin/SUMO protease protein 2 (SenP2), a gene linked to sumoylation and membrane trafficking of these same potassium ion channels in heart and brain, is a new member of this category (Qi et al. 2014). Interestingly, molecular autopsy of human SUDEP cases reveal that mutations of these genes can also form complex risk profiles, suggesting an opportunity for early prognosis and potential for intervention in this life-threatening condition (Klassen et al. 2014).

\section{CONCLUSION}

Systematic clinical databases that aggregate gene variants and their human phenotypes (Clinvar) (Landrum et al. 2014) will greatly contribute to our slowly emerging understanding of the genetic landscape of the epilepsy spectrum. Genetic etiologies also play a role in understanding iatrogenic treatment-induced comorbidity, and, in some cases, even absolving the drug of complicity. For example, the appearance of cerebellar abnormalities and rapid decline in motor function in Unverricht-Lundborg disease had been long attributed to phenytoinrelated cerebellar degeneration until the gene for this syndrome was identified and shown in animal models to produce mutation-driven cell death in these regions in the absence of the drug (Pennacchio et al. 1996, 1998). More recently, 
J.L. Noebels

concern that the encephalopathy of Dravet syndrome may be aggravated as a postvaccination reaction has been challenged by the observation that patients with SCN1A gene mutations show no worse cognitive function when vaccinated before seizure onset or not (McIntosh et al. 2010). In the future, molecular diagnosis may facilitate earlier and even presymptomatic recognition of comorbid neurobehavioral disorders in individuals with seizure disorders. This important change in our approach should accelerate a more holistic etiological understanding and more effective clinical management of epilepsy patients.

\section{ACKNOWLEDGMENTS}

This work is supported by Citizens United for Research in Epilepsy (CURE), National Institutes of Health (NIH)/National Institute of Neurological Disorders and Stroke (NINDS) NS 29709, U01 NS090340 (Center for SUDEP Research), and the Blue Bird Circle Foundation (J.L.N.).

\section{REFERENCES}

Amatniek JC, Hauser WA, DelCastillo-Castaneda C, Jacobs DM, Marder K, Bell K, Albert M, Brandt J, Stern Y. 2006. Incidence and predictors of seizures in patients with Alzheimer's disease. Epilepsia 47: 867-872.

Ayata C, Shimizu-Sasamata M, Lo EH, Noebels JL, Moskowitz MA. 2000. Impaired neurotransmitter release and elevated threshold for cortical spreading depression in mice with mutations in the $\alpha 1 \mathrm{~A}$ subunit of $\mathrm{P} / \mathrm{Q}$ type calcium channels. Neuroscience 95: 639-645.

Bender AC, Morse RP, Scott RC, Holmes GL, Lenck-Santini PP. 2012. SCN1A mutations in Dravet syndrome: Impact of interneuron dysfunction on neural networks and cognitive outcome. Epilepsy Behav 23: 177-186.

Betancur C. 2011. Etiological heterogeneity in autism spectrum disorders: More than 100 genetic and genomic disorders and still counting. Brain Res 1380: 42-77.

Bianchi R, Wong RKS, Merlin LR. 2012. Glutamate receptors in epilepsy: Group I mGluR-mediated epileptogenesis. In Jasper's basic mechanisms of the epilepsies (ed Noebels JL, et al.). National Center for Biotechnology Information, Bethesda, MD.

Bragatti JA, Bandeira IC, de Carvalho AM, Abujamra AL, Leistner-Segal S, Bianchin MM. 2014. Tryptophan hydroxylase 2 (TPH2) gene polymorphisms and psychiatric comorbidities in temporal lobe epilepsy. Epilepsy Behav 32: $59-63$.
Brennan TJ, Seeley WW, Kilgard M, Schreiner CE, Tecott LH. 1997. Sound-induced seizures in serotonin 5-HT2c receptor mutant mice. Nat Genet 16: 387-390.

Camacho A, Espin JC, Nunez N, Simon R. 2012. Levetiracetam-induced reversible autistic regression. Pediatr Neurol 47: 65-67.

Camfield PR. 2011. Definition and natural history of Lennox-Gastaut syndrome. Epilepsia 52: 3-9.

Catala M, Poirier J. 2012. Georges Marinesco (1863-1938): Neurologist, neurohistologist and neuropathologist. Rom J Morphol Embryol 53: 869-877.

Chao HT, Chen H, Samaco RC, Xue M, Chahrour M, Yoo J, Neul JL, Gong S, Lu HC, Heintz N, et al. 2010. Dysfunction in GABA signalling mediates autism-like stereotypies and Rett syndrome phenotypes. Nature 468: 263269.

Cipriani A, Reid K, Young AH, Macritchie K, Geddes J. 2013. Valproic acid, valproate and divalproex in the maintenance treatment of bipolar disorder. Cochrane Database Syst Rev 10: CD003196.

Cirrito JR, Yamada KA, Finn MB, Sloviter RS, Bales KR, May PC, Schoepp DD, Paul SM, Mennerick S, Holtzman DM 2005. Synaptic activity regulates interstitial fluid amyloid- $\beta$ levels in vivo. Neuron 48: 913-922.

Cramer JA, Wang ZJ, Chang E, Powers A, Copher R, Cherepanov D, Broder MS. 2014. Healthcare utilization and costs in adults with stable and uncontrolled epilepsy. Epilepsy Behav 31: 356-362.

Curatolo P, Bombardieri R, Jozwiak S. 2008. Tuberous sclerosis. Lancet 372: 657-668.

D’Agati E, Moavero R, Cerminara C, Curatolo P. 2009. Attention-deficit hyperactivity disorder (ADHD) and tuberous sclerosis complex. J Child Neurol 24: 1282-1287.

DeLorey TM, Handforth A, Anagnostaras SG, Homanics GE, Minassian BA, Asatourian A, Fanselow MS, Delgado-Escueta A, Ellison GD, Olsen RW. 1998. Mice lacking the $\beta 3$ subunit of the $\mathrm{GABA}_{\mathrm{A}}$ receptor have the epilepsy phenotype and many of the behavioral characteristics of Angelman syndrome. J Neurosci 18: 8505-8514.

De Rubeis S, He X, Goldberg AP, Poultney CS, Samocha K, Cicek AE, Kou Y, Liu L, Fromer M, Walker S, et al. 2014. Synaptic, transcriptional and chromatin genes disrupted in autism. Nature 515: 209-215.

Dolan BM, Duron SG, Campbell DA, Vollrath B, Shankaranarayana Rao BS, Ko HY, Lin GG, Govindarajan A, Choi SY, Tonegawa S. 2013. Rescue of fragile X syndrome phenotypes in Fmrl KO mice by the small-molecule PAK inhibitor FRAX486. Proc Natl Acad Sci 110: 5671-5676.

Dutta A, McKie S, Deakin JF. 2015. Ketamine and other potential glutamate antidepressants. Psychiatry Res 225: $1-13$.

Epps SA, Weinshenker D. 2013. Rhythm and blues: Animal models of epilepsy and depression comorbidity. Biochem Pharmacol 85: 135-146.

Gaborit N, Le Bouter S, Szuts V, Varro A, Escande D, Nattel S, Demolombe S. 2007. Regional and tissue specific transcript signatures of ion channel genes in the non-diseased human heart. J Physiol 582: 675-693.

Gatt JM, Burton KL, Williams LM, Schofield PR. 2015. Specific and common genes implicated across major mental 
disorders: A review of meta-analysis studies. J Psychiatr Res 60C: $1-13$.

Gheyara AL, Ponnusamy R, Djukic B, Craft RJ, Ho K, Guo W, Finucane MM, Sanchez PE, Mucke L. 2014. Tau reduction prevents disease in a mouse model of Dravet syndrome. Ann Neurol 76: 443-456.

Glasscock E, Yoo JW, Chen TT, Klassen TL, Noebels JL. 2010. $\mathrm{K}_{\mathrm{v}} 1.1$ potassium channel deficiency reveals brain-driven cardiac dysfunction as a candidate mechanism for sudden unexplained death in epilepsy. J Neurosci 30: 51675175.

Goldman AM, Glasscock E, Yoo J, Chen TT, Klassen TL, Noebels JL. 2009. Arrhythmia in heart and brain: KCNQ1 mutations link epilepsy and sudden unexplained death. Sci Transl Med 1: 2ra6.

Hartmann HA, Colom LV, Sutherland ML, Noebels JL. 1999. Selective localization of cardiac SCN5A sodium channels in limbic regions of rat brain. Nat Neurosci 2: 593-595.

Hernan AE, Alexander A, Lenck-Santini PP, Scott RC Holmes GL. 2014. Attention deficit associated with early life interictal spikes in a rat model is improved with ACTH. PloS ONE 9: e89812.

Heron SE, Grinton BE, Kivity S, Afawi Z, Zuberi SM, Hughes JN, Pridmore C, Hodgson BL, Iona X, Sadleir LG, et al. 2012a. PRRT2 mutations cause benign familial infantile epilepsy and infantile convulsions with choreoathetosis syndrome. Am J Hum Genet 90: 152-160.

Heron SE, Smith KR, Bahlo M, Nobili L, Kahana E, Licchetta L, Oliver KL, Mazarib A, Afawi Z, Korczyn A, et al. 2012b. Missense mutations in the sodium-gated potassium channel gene KCNT1 cause severe autosomal dominant nocturnal frontal lobe epilepsy. Nat Genet 44: $1188-1190$.

Hoffmann J, Akerman S, Goadsby PJ. 2014. Efficacy and mechanism of anticonvulsant drugs in migraine. Exp Rev Clin Pharmacol 7: 191-201.

Holmes GL. 2014. What is more harmful, seizures or epileptic EEG abnormalities? Is there any clinical data? Epileptic Disord 16: 12-22.

Holth JK, Bomben VC, Reed JG, Inoue T, Younkin L, Younkin SG, Pautler RG, Botas J, Noebels JL. 2013. Tau loss attenuates neuronal network hyperexcitability in mouse and Drosophila genetic models of epilepsy. J Neurosci 33: $1651-1659$.

Iossifov I, O’Roak BJ, Sanders SJ, Ronemus M, Krumm N, Levy D, Stessman HA, Witherspoon KT, Vives L, Patterson KE, et al. 2014. The contribution of de novo coding mutations to autism spectrum disorder. Nature 515: 216-221.

Jiang YH, Armstrong D, Albrecht U, Atkins CM, Noebels JL, Eichele G, Sweatt JD, Beaudet AL. 1998. Mutation of the Angelman ubiquitin ligase in mice causes increased cytoplasmic p53 and deficits of contextual learning and long-term potentiation. Neuron 21: 799-811.

Kanner AM. 2011. Depression and epilepsy: A bidirectiona relation? Epilepsia 52: 21-27.

Kanner AM, Schachter SC, Barry JJ, Hesdorffer DC, Mula M, Trimble M, Hermann B, Ettinger AE, Dunn D, Caplan R, et al. 2012. Depression and epilepsy: Epidemiologic and neurobiologic perspectives that may explain their high comorbid occurrence. Epilepsy Behav 24: 156-168.
Karayannis T, Au E, Patel JC, Kruglikov I, Markx S, Delorme R, Heron D, Salomon D, Glessner J, Restituito S, et al. 2014. Cntnap4 differentially contributes to GABAergic and dopaminergic synaptic transmission. Nature 511: 236-240.

Kidd SA, Lachiewicz A, Barbouth D, Blitz RK, Delahunty C, McBrien D, Visootsak J, Berry-Kravis E. 2014. Fragile X syndrome: A review of associated medical problems. Pediatrics 134: 995-1005.

Kim GE, Kaczmarek LK. 2014. Emerging role of the KCNT1 Slack channel in intellectual disability. Front Cell Neurosci 8: 209.

Klassen T, Davis C, Goldman A, Burgess D, Chen T, Wheeler D, McPherson J, Bourquin T, Lewis L, Villasana D, et al. 2011. Exome sequencing of ion channel genes reveals complex profiles confounding personal risk assessment in epilepsy. Cell 145: 1036-1048.

Klassen TL, Bomben VC, Patel A, Drabek J, Chen TT, Gu W, Zhang F, Chapman K, Lupski JR, Noebels JL, et al. 2014. High-resolution molecular genomic autopsy reveals complex sudden unexpected death in epilepsy risk profile. Epilepsia 55: e6-12.

Kleen JK, Scott RC, Lenck-Santini PP, Holmes GL. 2012. Cognitive and behavioral co-morbidities of epilepsy. In Jasper's basic mechanisms of the epilepsies (ed. Noebels JL, et al.). National Center for Biotechnology Information, Bethesda, MD.

Koh S, Magid R, Chung H, Stine CD, Wilson DN. 2007. Depressive behavior and selective down-regulation of serotonin receptor expression after early-life seizures: Reversal by environmental enrichment. Epilepsy Behav 10: 26-31.

Lacey CJ, Salzberg MR, D'Souza WJ. 2014. Serotonin transporter genexenvironment and risk of depression in community-treated epilepsy. Epilepsy Behav 39: 33-37.

LaFerla FM, Tinkle BT, Bieberich CJ, Haudenschild CC, Jay G. 1995. The Alzheimer's A $\beta$ peptide induces neurodegeneration and apoptotic cell death in transgenic mice. Nat Genet 9: 21-30.

Lancaster E, Dalmau J. 2012. Neuronal autoantigens-Pathogenesis, associated disorders and antibody testing. Nat Rev Neurol 8: 380-390.

Landrum MJ, Lee JM, Riley GR, Jang W, Rubinstein WS, Church DM, Maglott DR. 2014. ClinVar: Public archive of relationships among sequence variation and human phenotype. Nucleic Acids Res 42: D980-D985.

Li Z, Chang SH, Zhang LY, Gao L, Wang J. 2014. Molecular genetic studies of ADHD and its candidate genes: A review. Psychiatry Res 219: 10-24.

Lin JJ, Mula M, Hermann BP. 2012. Uncovering the neurobehavioural comorbidities of epilepsy over the lifespan. Lancet 380: 1180-1192.

Lipton JO, Sahin M. 2014. The Neurology of mTOR. Neuron 84: $275-291$.

Lo-Castro A, Curatolo P. 2014. Epilepsy associated with autism and attention deficit hyperactivity disorder: Is there a genetic link? Brain Dev 36: 185-193.

Lopera F, Ardilla A, Martinez A, Madrigal L, Arango-Viana JC, Lemere CA, Arango-Lasprilla JC, Hincapie L, ArcosBurgos M, Ossa JE, et al. 1997. Clinical features of early- 
J.L. Noebels

onset Alzheimer disease in a large kindred with an E280A presenilin-1 mutation. JAMA 277: 793-799.

Lund C, Brodtkorb E, Oye AM, Rosby O, Selmer KK. 2014. CHD2 mutations in Lennox-Gastaut syndrome. Epilepsy Behav 33: 18-21.

Matsuo M, Maeda T, Sasaki K, Ishii K, Hamasaki Y. 2010. Frequent association of autism spectrum disorder in patients with childhood onset epilepsy. Brain Dev 32: 759763.

Matsuura T, Yamagata T, Burgess DL, Rasmussen A, Grewal RP, Watase K, Khajavi M, McCall AE, Davis CF, Zu L, et al. 2000. Large expansion of the ATTCT pentanucleotide repeat in spinocerebellar ataxia type 10. Nat Genet 26: 191-194.

McIntosh AM, McMahon J, Dibbens LM, Iona X, Mulley JC, Scheffer IE, Berkovic SF. 2010. Effects of vaccination on onset and outcome of Dravet syndrome: A retrospective study. Lancet Neurol 9: 592-598.

Nestler EJ, Hyman SE. 2010. Animal models of neuropsychiatric disorders. Nat Neurosci 13: 1161-1169.

Nestler EJ, Barrot M, DiLeone RJ, Eisch AJ, Gold SJ, Monteggia LM. 2002. Neurobiology of depression. Neuron 34: $13-25$.

Noebels J. 2011. A perfect storm: Converging paths of epilepsy and Alzheimer's dementia intersect in the hippocampal formation. Epilepsia 52: 39-46.

Oncu B, Er O, Colak B, Nutt DJ. 2014. Lamotrigine for attention deficit-hyperactivity disorder comorbid with mood disorders: A case series. J Psychopharmacol 28: 282-283.

Ophoff RA, Terwindt GM, Vergouwe MN, van Eijk R, Oefner PJ, Hoffman SM, Lamerdin JE, Mohrenweiser HW, Bulman DE, Ferrari M, et al. 1996. Familial hemiplegic migraine and episodic ataxia type- 2 are caused by mutations in the $\mathrm{Ca}^{2+}$ channel gene CACNL1A4. Cell 87: $543-552$.

Ortolano S, Vieitez I, Agis-Balboa RC, Spuch C. 2014. Loss of GABAergic cortical neurons underlies the neuropathology of Lafora disease. Mol Brain 7: 7.

Ozkan ED, Creson TK, Kramar EA, Rojas C, Seese RR, Babyan AH, Shi Y, Lucero R, Xu X, Noebels JL, et al. 2014. Reduced cognition in Syngap1 mutants is caused by isolated damage within developing forebrain excitatory neurons. Neuron 82: 1317-1333.

Paemka L, Mahajan VB, Skeie JM, Sowers LP, Ehaideb SN, Gonzalez-Alegre P, Sasaoka T, Tao H, Miyagi A, Ueno N, et al. 2013. PRICKLE1 interaction with SYNAPSIN I reveals a role in autism spectrum disorders. PloS ONE 8: e80737.

Palop JJ, Chin J, Roberson ED, Wang J, Thwin MT, Bien-Ly N, Yoo J, Ho KO, Yu GQ, Kreitzer A, et al. 2007. Aberrant excitatory neuronal activity and compensatory remodeling of inhibitory hippocampal circuits in mouse models of Alzheimer's disease. Neuron 55: 697-711.

Pearson TS, Akman C, Hinton VJ, Engelstad K, De Vivo DC. 2013. Phenotypic spectrum of glucose transporter type 1 deficiency syndrome (Glutl DS). Curr Neurol Neurosci Rep 13: 342.

Pennacchio LA, Lehesjoki AE, Stone NE, Willour VL, Virtaneva K, Miao J, D'Amato E, Ramirez L, Faham M, Koskiniemi M, et al. 1996. Mutations in the gene encoding cystatin B in progressive myoclonus epilepsy (EPM1). Science 271: 1731-1734.

Pennacchio LA, Bouley DM, Higgins KM, Scott MP, Noebels JL, Myers RM. 1998. Progressive ataxia, myoclonic epilepsy and cerebellar apoptosis in cystatin B-deficient mice. Nat Genet 20: 251-258.

Pietrobon D, Moskowitz MA. 2013. Pathophysiology of migraine. Annu Rev Physiol 75: 365-391.

Powell EM, Campbell DB, Stanwood GD, Davis C, Noebels JL, Levitt P. 2003. Genetic disruption of cortical interneuron development causes region- and GABA cell typespecific deficits, epilepsy, and behavioral dysfunction. $J$ Neurosci 23: 622-631.

Price MG, Yoo JW, Burgess DL, Deng F, Hrachovy RA, Frost JD Jr, Noebels JL. 2009. A triplet repeat expansion genetic mouse model of infantile spasms syndrome, $\operatorname{Arx}^{(\mathrm{GCG}) 10+7}$, with interneuronopathy, spasms in infan$\mathrm{cy}$, persistent seizures, and adult cognitive and behavioral impairment. J Neurosci 29: 8752-8763.

Qi Y, Wang J, Bomben VC, Li DP, Chen SR, Sun H, Xi Y, Reed JG, Cheng J, Pan HL, et al. 2014. Hyper-SUMOylation of the Kv7 potassium channel diminishes the M-current leading to seizures and sudden death. Neuron 83: 11591171.

Reutlinger C, Helbig I, Gawelczyk B, Subero JI, Tonnies H, Muhle H, Finsterwalder K, Vermeer S, Pfundt R, Sperner J, et al. 2010. Deletions in 16p13 including GRIN2A in patients with intellectual disability, various dysmorphic features, and seizure disorders of the rolandic region. Epilepsia 51: 1870-1873.

Roberson ED, Halabisky B, Yoo JW, Yao J, Chin J, Yan F, Wu T, Hamto P, Devidze N, Yu GQ, et al. 2011. Amyloid- $\beta$ / Fyn-induced synaptic, network, and cognitive impairments depend on tau levels in multiple mouse models of Alzheimer's disease. J Neurosci 31: 700-711.

Rogawski MA. 2012. Migraine and epilepsy-shared mechanisms within the family of episodic disorders. In Jasper's basic mechanisms of the epilepsies (ed. Noebels JL, et al.). National Center for Biotechnology Information, Bethesda, MD.

Rothstein JD, Dykes-Hoberg M, Pardo CA, Bristol LA, Jin L, Kuncl RW, Kanai Y, Hediger MA, Wang Y, Schielke JP, et al. 1996. Knockout of glutamate transporters reveals a major role for astroglial transport in excitotoxicity and clearance of glutamate. Neuron 16: 675-686.

Royer-Zemmour B, Ponsole-Lenfant M, Gara H, Roll P, Leveque C, Massacrier A, Ferracci G, Cillario J, Robaglia-Schlupp A, Vincentelli R, et al. 2008. Epileptic and developmental disorders of the speech cortex: Ligand/ receptor interaction of wild-type and mutant SRPX2 with the plasminogen activator receptor uPAR. Hum Mol Genet 17: 3617-3630.

Russell MB, Ducros A. 2011. Sporadic and familial hemiplegic migraine: Pathophysiological mechanisms, clinical characteristics, diagnosis, and management. Lancet Neurol 10: 457-470.

Saitsu H, Kato M, Koide A, Goto T, Fujita T, Nishiyama K, Tsurusaki Y, Doi H, Miyake N, Hayasaka K, et al. 2012. Whole exome sequencing identifies KCNQ2 mutations in Ohtahara syndrome. Ann Neurol 72: 298-300.

Sanchez PE, Zhu L, Verret L, Vossel KA, Orr AG, Cirrito JR, Devidze N, Ho K, Yu GQ, Palop JJ, et al. 2012. Leveti- 
racetam suppresses neuronal network dysfunction and reverses synaptic and cognitive deficits in an Alzheimer's disease model. Proc Natl Acad Sci 109: E2895-E2903.

Selle V, Schalkwijk S, Vazquez GH, Baldessarini RJ. 2014. Treatments for acute bipolar depression: Meta-analyses of placebo-controlled, monotherapy trials of anticonvulsants, lithium and antipsychotics. Pharmacopsychiatry 47: 43-52.

Serikawa T, Yamada J. 1986. Epileptic seizures in rats homozygous for two mutations, zitter and tremor. J Hered 77: 441-444.

Sia GM, Clem RL, Huganir RL. 2013. The human languageassociated gene SRPX2 regulates synapse formation and vocalization in mice. Science 342: 987-991.

Singh NA, Charlier C, Stauffer D, DuPont BR, Leach RJ, Melis R, Ronen GM, Bjerre I, Quattlebaum T, Murphy JV, et al. 1998. A novel potassium channel gene, KCNQ2, is mutated in an inherited epilepsy of newborns. Nat Genet 18: 25-29.

Singh NA, Otto JF, Dahle EJ, Pappas C, Leslie JD, Vilaythong A, Noebels JL, White HS, Wilcox KS, Leppert MF. 2008. Mouse models of human KCNQ2 and KCNQ3 mutations for benign familial neonatal convulsions show seizures and neuronal plasticity without synaptic reorganization. J Physiol 586: 3405-3423.

Steinlein OK. 2014. Genetic heterogeneity in familial nocturnal frontal lobe epilepsy. Prog Brain Res 213: 1-15.

Steinlein OK, Mulley JC, Propping P, Wallace RH, Phillips HA, Sutherland GR, Scheffer IE, Berkovic SF. 1995. A missense mutation in the neuronal nicotinic acetylcholine receptor $\alpha 4$ subunit is associated with autosomal dominant nocturnal frontal lobe epilepsy. Nat Genet 11: 201-203.

Stromme P, Mangelsdorf ME, Shaw MA, Lower KM, Lewis SM, Bruyere H, Lutcherath V, Gedeon AK, Wallace RH, Scheffer IE, et al. 2002. Mutations in the human ortholog of Aristaless cause X-linked mental retardation and epilepsy. Nat Genet 30: 441-445.

Tanaka K, Watase K, Manabe T, Yamada K, Watanabe M, Takahashi K, Iwama H, Nishikawa T, Ichihara N, Kikuchi T, et al. 1997. Epilepsy and exacerbation of brain injury in mice lacking the glutamate transporter GLT-1. Science 276: $1699-1702$.

Tatum WOt, Ross J, Cole AJ. 1998. Epileptic pseudodementia. Neurology 50: 1472-1475.
Tellez-Zenteno JF, Patten SB, Jette N, Williams J, Wiebe S. 2007. Psychiatric comorbidity in epilepsy: A populationbased analysis. Epilepsia 48: 2336-2344.

Terrone G, Bienvenu T, Germanaud D, Barthez-Carpentier MA, Diebold B, Delanoe C, Passemard S, Auvin S. 2014 A case of Lennox-Gastaut syndrome in a patient with FOXG1-related disorder. Epilepsia 55: e116-e119.

Tottene A, Conti R, Fabbro A, Vecchia D, Shapovalova M, Santello M, van den Maagdenberg AM, Ferrari MD, Pietrobon D. 2009. Enhanced excitatory transmission at cortical synapses as the basis for facilitated spreading depression in $\mathrm{Ca}_{\mathrm{v}} 2.1$ knockin migraine mice. Neuron 61: $762-773$.

Tripathi PP, Di Giovannantonio LG, Viegi A, Wurst W, Simeone A, Bozzi Y. 2008. Serotonin hyperinnervation abolishes seizure susceptibility in Otx2 conditional mutant mice. J Neurosci 28: 9271-9276.

Vasudev A, Macritchie K, Rao SK, Geddes J, Young AH. 2012. Tiagabine for acute affective episodes in bipolar disorder. Cochrane Database Syst Rev 12: CD004694.

Velez-Pardo C, Arellano JI, Cardona-Gomez P, Jimenez Del Rio M, Lopera F, De Felipe J. 2004. CA1 hippocampal neuronal loss in familial Alzheimer's disease presenilin1 E280A mutation is related to epilepsy. Epilepsia 45: 751-756.

Vossel KA, Beagle AJ, Rabinovici GD, Shu H, Lee SE, Naasan G, Hegde M, Cornes SB, Henry ML, Nelson AB, et al. 2013. Seizures and epileptiform activity in the early stages of Alzheimer disease. JAMA Neurol 70: 1158-1166.

Wang D, Pascual JM, Yang H, Engelstad K, Mao X, Cheng J, Yoo J, Noebels JL, De Vivo DC. 2006. A mouse model for Glut-1 haploinsufficiency. Hum Mol Genet 15: 11691179.

Zhang W, Peterson M, Beyer B, Frankel WN, Zhang ZW. 2014. Loss of MeCP2 from forebrain excitatory neurons leads to cortical hyperexcitation and seizures. J Neurosci 34: 2754-2763.

Zhu PJ, Huang W, Kalikulov D, Yoo JW, Placzek AN, Stoica L, Zhou H, Bell JC, Friedlander MJ, Krnjevic K, et al. 2011. Suppression of PKR promotes network excitability and enhanced cognition by interferon- $\boldsymbol{\gamma}$-mediated disinhibition. Cell 147: 1384-1396.

Zuberi SM, Brunklaus A, Birch R, Reavey E, Duncan J, Forbes GH. 2011. Genotype-phenotype associations in SCN1A-related epilepsies. Neurology 76: 594-600. 


\section{$\&_{\mathrm{CSH}}^{\infty} \&$ Cold Spring Harbor

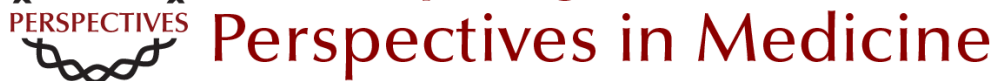

\section{Single-Gene Determinants of Epilepsy Comorbidity}

Jeffrey L. Noebels

Cold Spring Harb Perspect Med 2015; doi: 10.1101/cshperspect.a022756

Subject Collection Epilepsy: The Biology of a Spectrum Disorder

The Epilepsy Spectrum: Targeting Future

Research Challenges

Gregory L. Holmes and Jeffrey L. Noebels

Role of Sodium Channels in Epilepsy

David I. Kaplan, Lori L. Isom and Steven Petrou

\section{Mechanisms of Action of Antiseizure Drugs and the Ketogenic Diet \\ Michael A. Rogawski, Wolfgang Löscher and Jong M. Rho}

Epilepsy and Autism

Ashura W. Buckley and Gregory L. Holmes

Immunity and Inflammation in Epilepsy Annamaria Vezzani, Bethan Lang and Eleonora Aronica

Hyperpolarization-Activated Cyclic

Nucleotide-Gated (HCN) Channels in Epilepsy Gary P. Brennan, Tallie Z. Baram and Nicholas P. Poolos

The Role of Calcium Channels in Epilepsy Sanjeev Rajakulendran and Michael G. Hanna Interneuron Transplantation as a Treatment for Epilepsy

Robert F. Hunt and Scott C. Baraban

\section{Common Mechanisms Underlying \\ Epileptogenesis and the Comorbidities of \\ Epilepsy \\ Andrey Mazarati and Raman Sankar}

The Diathesis-Epilepsy Model: How Past Events Impact the Development of Epilepsy and Comorbidities

Christophe Bernard

Potassium Channels in Epilepsy

Rüdiger Köhling and Jakob Wolfart

\section{GABAergic Synchronization in Epilepsy Roustem Khazipov \\ Status Epilepticus Syndi Seinfeld, Howard P. Goodkin and Shlomo Shinnar}

Neonatal and Infantile Epilepsy: Acquired and Genetic Models Aristea S. Galanopoulou and Solomon L. Moshé

Epigenetics and Epilepsy David C. Henshall and Katja Kobow

Microcircuits in Epilepsy: Heterogeneity and Hub Cells in Network Synchronization Anh Bui, Hannah K. Kim, Mattia Maroso, et al.

For additional articles in this collection, see http://perspectivesinmedicine.cshlp.org/cgi/collection/ 